\title{
Evaluating the adequacy of reserves in the Tembe-Tshanini Complex: a case study in Maputaland, South Africa
}

\author{
J.Y. GA U G IS and M.W. VAN ROOYEN
}

\begin{abstract}
The aim of this study was to determine the minimum conservation area needed to conserve vegetation types and their landscape and to apply it to an area in KwaZulu-Natal, South Africa, which is within the Maputaland Centre of Plant Endemism and part of the Maputaland-Pondoland-Albany biodiversity hotspot. Outside conservation areas this Centre of Plant Endemism is under threat from human utilization. We used a method initially designed to determine minimum conservation areas for rare plant species, which we adapted from its original country and context, to determine minimum conservation areas for landscape species in Maputaland's little-documented environment. The minimum area required for conservation was established for the Sand Forest and Woodland vegetation types in the region. We found that sufficient habitat is presently conserved to preserve the Sand Forest but not the Woodlands. The method holds promise to provide answers to critical conservation issues in lesser-known environments and, although relatively difficult to establish for the first time, is an efficient and easy to use tool that can be refined once more knowledge becomes available.
\end{abstract}

Keywords Maputaland, minimum conservation area, Sand Forest, South Africa, sustainable utilization, woodland vegetation

This paper contains supplementary material that can be found online at http://journals.cambridge.org

\section{Introduction}

Tn most developing countries the human population 1 increase of the past 50 years has been linked with a significant increase in natural resource exploitation (Naughton-Treves et al., 2007) and this has been most severe for wood (Luoga et al., 2000). Although protected areas represent an appropriate way to conserve natural resources they are usually inadequate in size and do not cover the full range of features in need of conservation

J.Y. GAugris* (Corresponding author) Centre for Wildlife Management, University of Pretoria, 0002 Pretoria, South Africa. E-mail kiboko@ florafaunaman.com

M.W. VAN Rooyen Department of Plant Science, University of Pretoria, Pretoria, South Africa

Received 26 December 2007. Revision requested 2 April 2008.

Accepted 21 May 2008.
(Pressey et al., 2003). Consequently, there is a need to conserve resources outside formally protected areas by creating a network of formal conserved areas interlinked by a matrix that creates corridors for plant and animal dispersal (Rouget et al., 2006; Smith et al., 2006).

One of the key issues in systematic conservation planning is to determine how much needs to be protected (Eeley et al., 2001; Sanderson et al., 2002). Setting targets has been the crux of conservation planning since the $10 \%$ global landmass target proposed at the 3 rd World Congress on National Parks in 1982 (Pressey et al., 2003; Tear et al., 2005). However, such targets have promoted the protection of land irrespective of its value for conservation.

Setting targets is currently achieved by integrating the sum of individual targets of all landscape features (soils, topography, climate, plants, animals) to derive a regional target (Pressey et al., 2003). Regional targets are then used to assess the effectiveness of current conservation areas and develop new management plans. The most severe limitation for setting such targets lies in the lack of biodiversity data, which in some cases could imply that short of conserving $100 \%$ of a region, conservation will fail its purpose (Pressey et al., 2003). Moreover, targets should preferably describe quantitative aspects, as they are more tangible and facilitate further use and refinements, rather than qualitative aspects. Quantitative targets are constructed from evidence, and are therefore defensible.

Setting broad-scale conservation targets requires reviewing smaller scale targets, and assimilating these with conservation planning software (Desmet \& Cowling, 2004). Such software exists for the selection of priority areas for conservation but tends to be most effective at a broad geographical scale (Eeley et al., 2001; Reyers et al., 2001; Pressey et al., 2003). Such regional overviews are based on a review of local expert judgement within the region of concern (Cowling et al., 2003). However, local experts seldom have the time or budget for the detailed, longterm population viability analyses and habitat modelling (Burgman et al., 2001; Desmet \& Cowling, 2004) required for setting scientifically and ecologically acceptable targets at the local scale. As a consequence, expert opinion at the local scale is usually more qualitative than quantitative. Methods that can assist establishment of quantitative conservation targets at the local level are therefore indispensable. Such methods should be simple, easy to use, sufficiently adaptable to incorporate new data, and should 
work with a limited amount of relevant information such as is typically gathered from baseline ecological studies. Such studies are often the only data available to conservation authorities (Burgman et al., 2001).

Burgman et al. (2001) developed such a method for setting conservation targets for plant species when there is insufficient data and time. They applied their method to rare plant species because such species usually require a specific conservation action. In this study we expand this method, evaluating its applicability for landscape species, where landscape species are a derivative of umbrella species (Sanderson et al., 2002). Landscape species are defined as biological entities occurring over large, ecologically diverse areas and having a significant impact on structure and function of local natural ecosystems within a timespan applicable to human management targets (Sanderson et al., 2002). Through conservation of landscape species the conservation of the whole landscape and the co-occurring species could potentially be achieved.

Conserving umbrella species based on a prospective selection of occurrence patterns and ecological traits (Fleishman et al., 2001) may be a good short-cut for conserving co-occurring species. However, umbrella species are often poorly selected and results may therefore fall short of expectations. Selection based on conservation status, failure to assess co-occurrence of similar taxonomic groups and species richness across the target landscape, and selection of habitat generalists are common pitfalls in umbrella species selection. The amount of information required to select an umbrella species properly may render it anything but a short-cut (Seddon \& Leech, 2008). The ideal umbrella species should be neither rare nor ubiquitous, and offer a significant chance of co-occurrence with other species (Fleishman et al., 2001). A recent revision of the umbrella species concept narrowed the selection criteria to seven from 17 in an attempt to provide a simpler concept (Seddon \& Leech, 2008). These seven criteria are: wellknown biology, large home range, high probability of population persistence, co-occurrence of species of conservation interest, management needs not specifically beneficial only to the umbrella species, moderate sensitivity to human disturbance, and ease of monitoring. This revision is therefore similar to the broader concept of landscape species that rely on five criteria: area requirements, heterogeneity in habitat utilization, ecological functionality, vulnerability to human land-uses and socio-economic significance. Therefore, by selecting appropriate landscape plant species we believe that most co-occurring common and rare plant species will be included, and to some extent the animals that depend upon them, which may make the conservation of these landscape plants an effective tool for conservation purposes.

By adapting and applying the method of Burgman et al. (2001) over a geographical region identified by systematic conservation planning as important for biodiversity con- servation (Eeley et al., 2001; Smith et al., 2006), our aim is to determine the minimum area of each vegetation community that needs to be fully conserved in a network of conservation areas.

\section{Study area}

The study area lies in the Maputaland region of South Africa, with two existing conservation sites: Tembe Elephant Park (30,000 ha) and Tshanini Community Conservation Area $(2,420 \mathrm{ha})$ in the Manqakulane rural community. Maputaland is the northern tip of the Maputaland-Pondoland-Albany biodiversity hotspot (Smith et al., 2006). It consists of a sandy plain interspersed with ancient littoral dunes that lie northsouth, covered by a mosaic of Sparse to Closed Woodland with patches of Sand Forest (Matthews et al., 2001; Gaugris et al., 2004; Gaugris, 2008).

The four main vegetation types are: Sand Forest, and Closed, Open and Sparse Woodland (Gaugris, 2008; Gaugris \& Van Rooyen, 2008), the latter best described as a wooded grassland. Sand Forest is biologically the most diverse vegetation type in Maputaland and one of the most important in the Maputaland-Pondoland-Albany hotspot (Matthews, 2006). However, Maputaland's woodlands are nearly as species rich as the Sand Forest (Matthews, 2006). Vegetation dynamics in the region are not fully understood but they may be driven by relatively frequent small-scale disturbances from incursions by large mammals (Gaugris, 2008). Largescale disturbances induced by increasing human populations outside conserved areas and high densities of large mammals inside conserved areas are challenging the resilience of both forest and woodland ecosystems (Botes et al., 2006; Gaugris, 2008).

\section{Methods}

While keeping to the same terminology, we used and adapted the method of Burgman et al. (2001) to suit our approach and the conditions of our case study. This 12-step method (Fig. 1) provides a framework within which knowledge of each selected species can be evaluated, thereby facilitating a discussion about how best to calculate the area required to protect groups of associated species. Apart from changes described immediately below, the modifications to the original method are described in our description of the 12 steps. We have tried to keep the methodology as simple as possible to make it accessible.

One of the main modifications is with regards to disturbance region, which we define to be a fixed area of a size that is susceptible to be fully disturbed by at least one disturbance within the time frame of that disturbance and subject to the same decision-making governance. We thus set the size of a disturbance region to 3,600 ha, which is approximately half the area of a rural community's tribal 
Mapping \& qualitative process (coarse filter) In relation to the local context

\begin{tabular}{|l|l|}
\hline $\begin{array}{l}\text { Recommended } \\
\text { Focus panel }\end{array}$ & $\begin{array}{l}\text { Social scientist } \\
\text { Ecologist } \\
\text { Vegetation sepcialist }\end{array}$ \\
\hline
\end{tabular}

Mathematical \& quantitative process (fine filter)

In relation to the local context

\begin{tabular}{|l|l|}
\hline $\begin{array}{l}\text { Recommended } \\
\text { Focus panel }\end{array}$ & $\begin{array}{l}\text { Social scientist } \\
\text { Ecologist } \\
\text { Vegetation specialist }\end{array}$ \\
\hline
\end{tabular}

Independently of the local context

\begin{tabular}{|l|l|}
\hline $\begin{array}{l}\text { Recommended } \\
\text { Focus panel }\end{array}$ & $\begin{array}{l}\text { Ecologist } \\
\text { Vegetation specialist }\end{array}$ \\
\hline
\end{tabular}

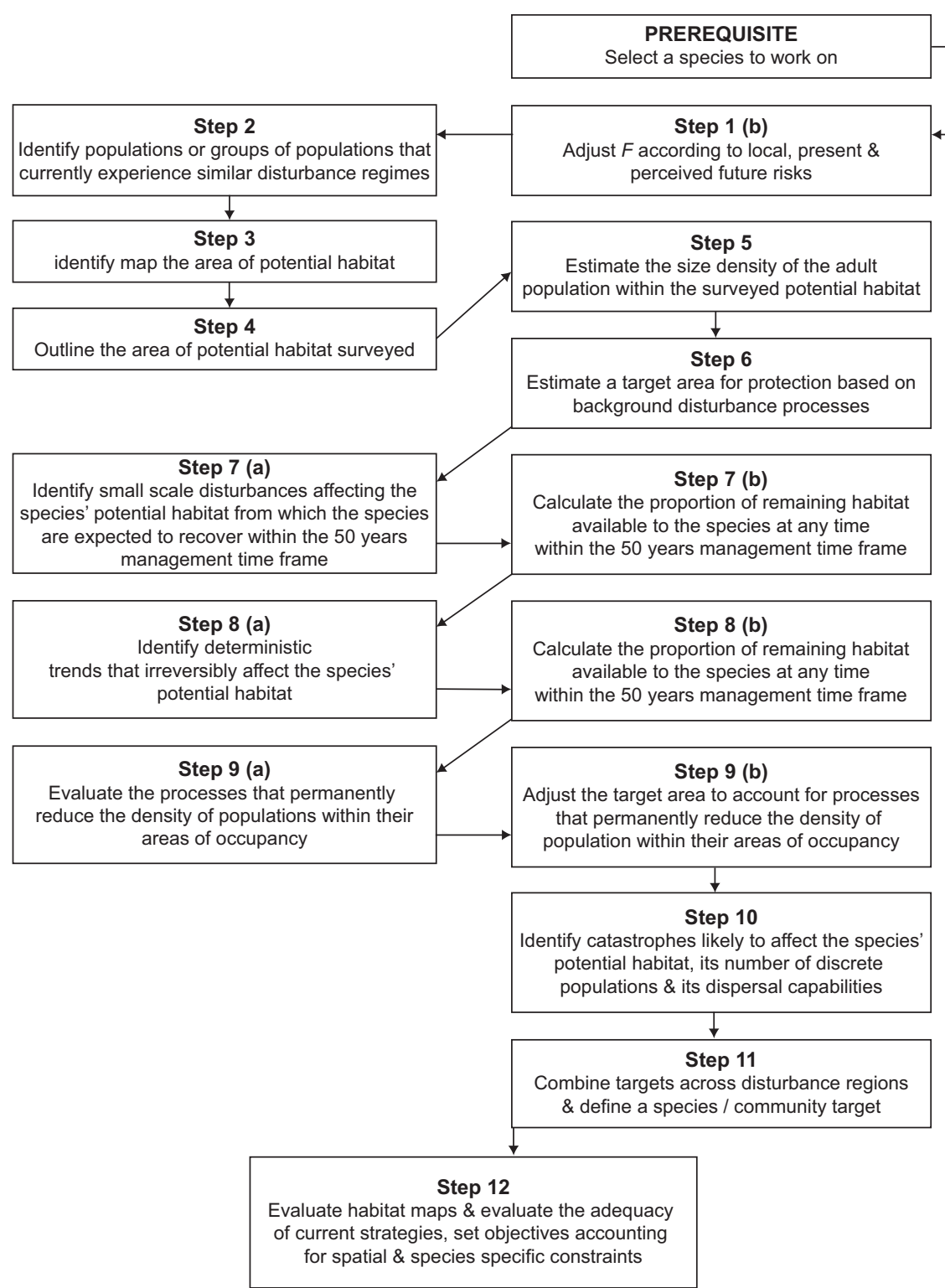

Fig. 1 The process flow chart of the 12 steps in the method of Burgman et al. (2001). The method is a combination of coarse (large scale for the regional level) and fine (local scale) considerations, with qualitative and quantitative inputs. The method should ideally be conducted by a panel of experts or people with local knowledge, who guide the decision process and assess the various risks considered. Step 12 is the bridge between qualitative and quantitative aspects.

land in Maputaland (Peteers, 2005). This size is also slightly less than half of the area for reliable representation of meteorological conditions around a meteorological station (Yeh et al., 2000). These two considerations ensured that each region could be considered homogeneous with respect to human-related disturbance or localized weather events, thereby incorporating both human and local weather variability within their respective time frames.
We view uncertainty differently to Burgman et al. (2001), who considered that high key (all is well) and low key (all is bad) analyses should be conducted in parallel to provide an uncertainty range reminiscent of interval arithmetic. To do this they noted that in most cases these high and low keys will have to be set subjectively. In our approach we evaluated the minimum viable population size $(F$, see definition below) in an area of $36 \times 42 \mathrm{~km}$ divided 
into a grid of 42 square disturbance regions of 3,600 ha, and assumed that the variation within the 42 regions provided a reasonable estimate of uncertainty, with upper and lower bounds based on evaluated threats, thus avoiding running parallel supplementary analyses. In effect, we applied the method to each disturbance region in the area, as Burgman et al. (2001) suggest. This approach to uncertainty was justified by the fact that most of the 42 regions have a similar ecological potential (Gaugris et al., 2004) but are subjected to different land tenure and land use.

Prerequisites Our method requires the selection of one or two plant species that are characteristic of a particular vegetation type. The species must represent the vegetation type in such a way that their conservation ensures the conservation of the vegetation type as a whole, including its dynamics (Burgman et al., 2001). Our choice of plant species followed recommendations for landscape species selection (Sanderson et al., 2002). Cleistanthus schlechteri (Pax) Hutch. and Newtonia hildebrandtii (Vatke) Torre were chosen as landscape tree species of the Sand Forest. Both grow into large canopy trees, are long-lived, have a wide geographical range in southern Africa (Pooley, 1997), and are used for firewood and building material (Gaugris et al., 2007). Hymenocardia ulmoides Oliv. and Sclerocarya birrea (A. Rich.) Hochst. were the landscape tree species chosen for the Woodlands. H. ulmoides is an abundant species, geographically widespread in KwaZulu-Natal, and it provides good building material (Pooley, 1997). S. birrea is an important food tree in southern Africa and is geographically widespread on the subcontinent (Emanuel et al., 2005).

Step 1 The method firstly requires the establishment of $F$, the minimum viable population size, defined as 'the population size that faces a $0.1 \%$ probability of falling below 50 adults at least once in the next 50 years, assuming no detrimental human effects' (Burgman et al., 2001). This represents a quasi extinction risk and provides a background risk against which it is possible to measure the utility of conservation actions. The 50 years benchmark reflects concerns for risks over which current management decisions may be effective. In the original method $F$ is the result of a combination of life table data and adjustment factors evaluated together. The method was, however, originally applied to well-documented plant species, which is not the case for the plant species of Maputaland. Because we believe that the method should be available to non-specialists and practitioners as well as being applicable to species for which only baseline survey data are available, we developed an empirical method to derive $F$. We first established the value of $F$ (Step 1a), which is the minimum viable population size independent of the local conditions of the targeted region. In Step $1 b, F$ is adjusted to reflect local conditions.

To determine $F$ we used published data from detailed studies (Burgman et al., 2001) of $F$-values against life expectancies of Banksia cuneata (Australia: $F=6,400$, life expectancy $=50$ years), Banksia goodii (Australia: $F=300$, life expectancy $=300$ years), Alnus incana (Northern Europe: $F=750$, life expectancy $=20$ years) and Pentaclethra macroloba (Amazon basin: $F=2,300$, life expectancy $=100$ years). Four equations were fitted to the available data to determine which best described the relationship: $y=$ $a(x)+b, y=a \ln (x)+b, y=a(x)^{b}$, and $y=a \mathrm{e}^{b(x)}$, where $a$ and $b$ are constants. The regression with the best fit (i.e. the highest coefficient of determination, $R^{2}$ ) was selected to calculate $F$ for each of the landscape species selected for our case study.

Adjusted $F$ is based on available knowledge regarding the species and environmental factors in the target area (Burgman et al., 2001). Thus, based on all available knowledge and expert opinion, $F$ can be increased or reduced to accommodate the effects of environmental conditions in the target area on the species' biology. We consider the value of $F$ estimated in Step 1 to be the minimum viable population size and therefore adjusted $F$ could only be $\geq F$. Our decision to set the maximum adjustment value to $2 F$ was subjective and based on personal knowledge of the area. Such subjective decisions are allowed in the original methodology as long as the person making the decision is reasonably qualified as an expert for the area concerned.

To establish the adjusted $F$-value we used the list of 25 ecological factors of Burgman et al. (2001). Each factor had two alternative states: one related to species resilience and one to species vulnerability (Table 1). Each factor was investigated and a numerical value assigned per factor to derive an ecological factor score. This score was used to generate the adjusted $F$-value. If the available knowledge of the species was insufficient to obtain a reliable answer a value of $o$ was given to both resilience and vulnerability. If it was possible to answer a question reliably then +1 was given for resilience or -1 for vulnerability. The ecological factor score was obtained by summing the resilience and vulnerability scores, and plotting the sum on a scale ranging from 25 (all questions pertaining to resilience assigned +1 ), thereby requiring no adjustment of $F$, to a low of -25 (all questions pertaining to vulnerability assigned -1 ) requiring maximum adjustment ( $F$ is doubled). The adjustment factor value was calculated as a fraction of the total potential for adjustment, based on the ecological factor score, and was added to $F$ to obtain the adjusted $F$-value (Table 1).

Step 2 The $36 \times 42 \mathrm{~km}$ area encompasses both Tembe Elephant Park and Tshanini Community Conservation Area (Fig. 2). The region was not fully surveyed and therefore only available geographical elements known from field surveys are provided as mapped elements in Fig. 2. The unmapped sections were evaluated by analysing topographical maps and 1:50,000 aerial photographs. The 
TABLE 1 Factors considered in the determination of the ecological factor score and thus the adjustment factor for the minimum viable population size ( $F$ ), as required for Step 1 (Fig. 1) for each of the four selected landscape tree species (see text for details) in the Tembe Elephant Park-Tshanini Conservation Area complex, Maputaland (Fig. 2).

\begin{tabular}{|c|c|c|c|c|c|c|c|c|c|c|}
\hline & Positive criteria (indicator & Negative criteria (indicator of & & rdia & $\begin{array}{l}\text { Scle } \\
\text { birr }\end{array}$ & & $\begin{array}{l}\text { Clei } \\
\text { schl }\end{array}$ & & $\begin{array}{l}\text { Ner } \\
\text { hild }\end{array}$ & \\
\hline & of resilience; $F+$ ) & vulnerability; $F-)$ & $F+$ & $F-$ & $F+$ & $F-$ & $F+$ & $F-$ & $F+$ & $F-$ \\
\hline 1 & Many large populations & Few small isolated populations & 1 & 0 & 1 & 0 & 1 & 0 & 1 & 0 \\
\hline 2 & Widespread distribution & Restricted distribution & 1 & 0 & 1 & 0 & 0 & -1 & 1 & 0 \\
\hline 3 & Habitat generalist & Habitat specialist & 1 & 0 & 1 & 0 & 0 & -1 & 0 & -1 \\
\hline 4 & Not restricted to a temporal niche & Restricted to a temporal niche & 0 & 0 & 0 & 0 & 0 & -1 & 0 & -1 \\
\hline 5 & Not subject to extreme habitat fluctuations & Subject to extreme habitat fluctuations & 1 & 0 & 1 & 0 & 1 & 0 & 1 & 0 \\
\hline 6 & No particular genetic vulnerability & Genetic vulnerability & 1 & 0 & 1 & 0 & 0 & 0 & 0 & 0 \\
\hline 7 & Vigorous post-disturbance regeneration & Weak post-disturbance regeneration & 1 & 0 & 0 & -1 & 1 & 0 & 0 & -1 \\
\hline 8 & Rapid vigorous growth & Slow weak growth & 1 & 0 & 0 & 0 & 1 & 0 & 0 & 0 \\
\hline 9 & Quickly achieves site dominance & Poor competitor & 1 & 0 & 0 & 0 & 1 & 0 & 0 & 0 \\
\hline 10 & All life stages resilient & Particular life stages vulnerable & 1 & 0 & 1 & 0 & 0 & 0 & 0 & 0 \\
\hline 11 & Short time to set first seed or propagules & Long time to set first seed or propagules & 0 & 0 & 0 & 0 & 1 & 0 & 1 & 0 \\
\hline 12 & Long reproductive lifespan & Short reproductive lifespan & 1 & 0 & 1 & 0 & 1 & 0 & 1 & 0 \\
\hline 13 & Robust breeding system & Dysfunctional breeding system & 1 & 0 & 1 & 0 & 1 & 0 & 1 & 0 \\
\hline 14 & Readily pollinated & Not readily pollinated & 1 & 0 & 1 & 0 & 1 & 0 & 1 & 0 \\
\hline 15 & Reliable seed production & Unreliable seed production & 1 & 0 & 1 & 0 & 1 & 0 & 0 & 0 \\
\hline 16 & High seed production & Low seed production & 1 & 0 & 1 & 0 & 1 & 0 & 1 & 0 \\
\hline 17 & Long seed or propagule viability & Short seed or propagule viability & 0 & -1 & 0 & -1 & 0 & -1 & 0 & 0 \\
\hline 18 & $\begin{array}{l}\text { Seed or propagule not exhausted by } \\
\text { disturbance }\end{array}$ & $\begin{array}{l}\text { Seed or propagule exhausted by } \\
\text { disturbance }\end{array}$ & 0 & 0 & 0 & -1 & 0 & 0 & 0 & 0 \\
\hline 19 & Good dispersal & Poor dispersal & 1 & 0 & 1 & 0 & 0 & 0 & 0 & -1 \\
\hline 20 & Generally survives fire \& other damage & Generally killed by fire \& other damage & 1 & 0 & 1 & 0 & 1 & 0 & 0 & 0 \\
\hline 21 & $\begin{array}{l}\text { Not adversely affected by pre-1600 } \\
\text { disturbance }^{1}\end{array}$ & $\begin{array}{l}\text { Adversely affected by pre-1600 } \\
\text { disturbance }^{1}\end{array}$ & 0 & 0 & 0 & 0 & 0 & 0 & 0 & 0 \\
\hline 22 & $\begin{array}{l}\text { Adapted to existing grazing, drought, } \\
\text { fire-regime }\end{array}$ & $\begin{array}{l}\text { Not adapted to existing grazing, drought, } \\
\text { fire-regime }\end{array}$ & 1 & 0 & 1 & 0 & 1 & 0 & 1 & 0 \\
\hline 23 & Able to coppice \& resprout & Unable to coppice \& resprout & 1 & 0 & 0 & 0 & 1 & 0 & 0 & 0 \\
\hline 24 & $\begin{array}{l}\text { Not vulnerable to pathogens, diseases, } \\
\text { insects, etc. }\end{array}$ & $\begin{array}{l}\text { Vulnerable to pathogens, diseases, } \\
\text { insects, etc. }\end{array}$ & 0 & 0 & 0 & 0 & 0 & 0 & 0 & 0 \\
\hline 25 & Not dependent on vulnerable mutualist & Dependent on vulnerable mutualist & 1 & 0 & 1 & 0 & 1 & 0 & 0 & 0 \\
\hline To & & & 19 & -1 & 15 & -3 & 15 & -4 & 9 & -4 \\
\hline & gical factor score $(\mathrm{EFS})(F+)+(F-)$ & & 18 & & 12 & & 11 & & 5 & \\
\hline & stment factor $(\mathrm{AF})^{2}$ & & +14 & $f(F)$ & +26 & $\mathrm{f}(F)$ & +28 & $(F)$ & +40 & $\mathrm{f}(F)$ \\
\hline
\end{tabular}

${ }^{1}$ Represents any large scale, landscape shaping disturbance known to have occurred prior to the colonization of South Africa by Europeans

${ }^{2}$ To calculate the adjustment factor the following scale is used: if $\mathrm{EFS}=+25$ then $\mathrm{AF}=+0 \%$ of $F$, if $\mathrm{EFS}=0$ then $\mathrm{AF}=+50 \%$ of $F$, if $\mathrm{EFS}=-25$ then $\mathrm{AF}=+100 \%$ of $F$. For example, for $N$. hidebrandtii the minimum viable population size $(F)=186.0$, the $\mathrm{AF}$ value $(40 \%$ of 186.0$)=74.4$ individuals, and the Adjusted $F$ value $=186.0+74.4=260.4$. As we only work with whole individuals a rounded Adjusted $F$ of 260.0 is used. 


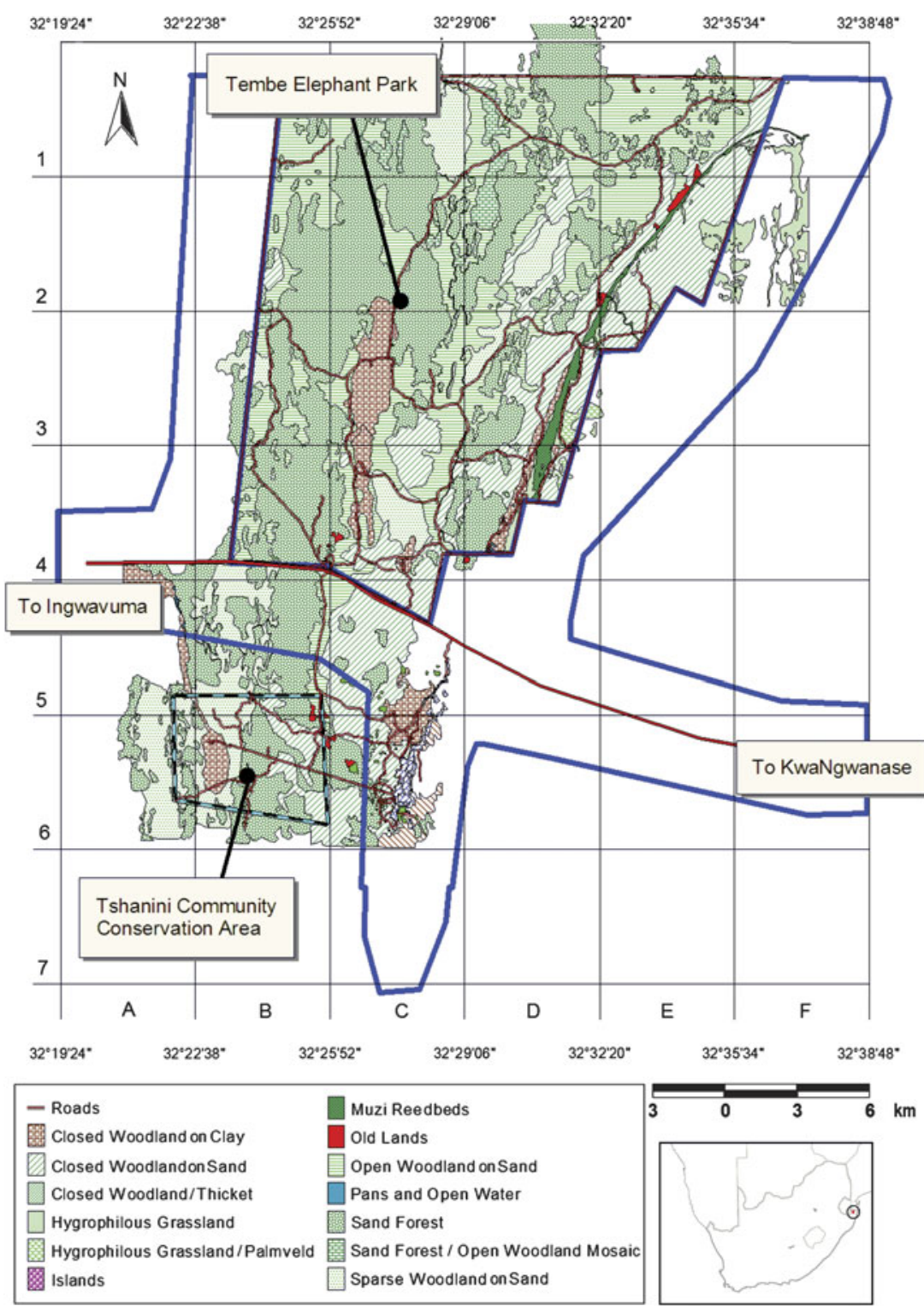

FIg. 2 Tembe Elephant Park and Tshanini Community Conservation Area in Maputaland, the region evaluated for establishing a minimum viable area for conservation using the method of Burgman et al. (2001). Individual grid squares are referred to in the text using the letters and numbers (e.g. D3). The area enclosed by the thick blue line indicates where development is expected to occur and to modify the landscape irreversibly within the next 50 years. The inset in the bottom right hand corner indicates the location of Maputaland in KwaZulu-Natal province, South Africa. disturbance level in each of the 42 squares was categorized as either sustainable (insignificant disturbance), light (light to moderate disturbance linked to human activity such as resource gathering) or heavy (moderate to heavy disturbance associated with human settlements and roads).

Step 3 The potential habitat per disturbance region (defined as the area capable of supporting viable populations of the selected landscape species, and characterized by climatic and/ or environmental parameters necessary to support the successful establishment of the selected plant species) was evaluated either directly using knowledge from fieldwork within the surveyed areas or estimated when fieldwork-based knowledge was unavailable. Overall it was estimated that 29,000 ha could potentially support Sand Forest vegetation and 62,991 ha could support Woodland vegetation.

Step 4 All the potential habitat area that was physically surveyed was mapped, and consisted of the sum of the area of Tembe Elephant Park and of the disturbance region in which the Tshanini Community Conservation Area occurs. The total potential habitat surveyed amounted to 33,600 ha, of which 5,600 ha and 28,000 ha were surveyed in Sand Forest and Woodland vegetation respectively (Gaugris, 2008). Of the 28,000 ha of Woodland, 12,200 ha was of Closed Woodland and 15,80o ha of Open Woodland.

Step 5 The density of mature trees per ha $(D)$ was obtained from detailed field surveys (Gaugris, 2008) in the Tshanini Community Conservation Area (disturbance region B6, Fig. 2) and Tembe Elephant Park (disturbance regions B1B5, C1-C5, D1-D4, E1-E3 and F1-F2; Fig. 2). To account for human utilization, tree density outside these disturbance regions was taken as the weighted mean of the values of both conservation areas, reduced by $10 \%$. To calculate $D$ (Step 5; Table 2) in the Sand Forest, mature C. schlechteri and $N$. hildebrandtii trees were considered as those having 
TAвLE 2 Baseline information required to establish the minimum conservation areas for the four vegetation types studied in Maputaland (Fig. 2). For each of the four landscape species the following information is provided: the theoretical life expectancy (based on a literature search), the minimum viable population size ( $F$, the number of individuals), the adjusted $F$ value calculated to compensate for known life history characteristics of the species and environmental characteristics of the area (Table 1), and the mean density (number of individuals per ha) of mature trees in the Tshanini Community Conservation Area, Tembe Elephant Park and unprotected areas.

\begin{tabular}{|c|c|c|c|c|c|c|}
\hline \multirow[b]{2}{*}{ Species } & \multirow[b]{2}{*}{$\begin{array}{l}\text { Life expectancy } \\
\text { (years) }\end{array}$} & \multirow[b]{2}{*}{$F$} & \multirow[b]{2}{*}{ Adjusted $F$} & \multicolumn{3}{|c|}{ Density of mature trees (D) } \\
\hline & & & & $\begin{array}{l}\text { Tshanini Community } \\
\text { Conservation Area }\end{array}$ & $\begin{array}{l}\text { Tembe Elephant } \\
\text { Park }\end{array}$ & $\begin{array}{l}\text { Unprotected } \\
\text { areas }\end{array}$ \\
\hline \multicolumn{7}{|l|}{ Sand Forest } \\
\hline C. schlechteri & 250 & 536 & 678 & 133.0 & 101.0 & 94.5 \\
\hline N. hildebrandtii & 400 & 186 & 260 & 80.0 & 35.0 & 34.2 \\
\hline \multicolumn{7}{|l|}{ Closed Woodland } \\
\hline H. ulmoides & 150 & 1,086 & 1,218 & 125.0 & 71.0 & 67.0 \\
\hline S. birrea & 300 & 374 & 471 & 75.0 & 21.0 & 20.0 \\
\hline \multicolumn{7}{|l|}{ Open Woodland } \\
\hline H. ulmoides & 150 & 1,086 & 1,218 & 411.0 & 13.0 & 30.0 \\
\hline S. birrea & 300 & 374 & 471 & 26.0 & 22.0 & 20.0 \\
\hline \multicolumn{7}{|l|}{ Sparse Woodland } \\
\hline H. ulmoides & 150 & 1,086 & 1,218 & 64.0 & 2.0 & 5.0 \\
\hline
\end{tabular}

a diameter $\geq 127 \mathrm{~mm}$ at breast height. In the Woodland, mature $S$. birrea and $H$. ulmoides trees were considered as those having a diameter $\geq 95.5 \mathrm{~mm}$ and $\geq 16 \mathrm{~mm}$ at breast height respectively.

Step 6 The determination of the minimum area required for conservation started by establishing the 'target area based on background disturbance processes, also called raw target area for reserve creation' (Burgman et al., 2001), which was calculated as Target Area $\left(A_{\mathrm{o}}\right)=$ Adjusted F/D. This target area, calculated per disturbance region, is an absolute minimum area required to support the target species assuming there is no threat. It is a preliminary value that does not take into consideration other known disturbances that can be measured and planned for.

Step 7 Sociological studies, maps and photographs were used to determine the additional small-scale disturbances from which species are expected to recover within a 50-year time frame but that will effectively reduce the potential habitat available. These disturbances were expressed as a percentage of a disturbance region that would become unavailable during the time frame considered, from which the percentage of remaining habitat $(S)$ of the disturbance region is calculated. This represents an evaluation of potential habitat that will become temporarily disturbed but that is considered likely to become suitable again provided enough time is given or appropriate management actions are taken. We considered here all activities that modify the canopy (cutting of trees) and sometimes the topsoil but not the seed bank (non-mechanized slash-andburn).

Step 8 The area expected to become irreversibly damaged within 50 years through human developments $\left(c_{i}\right)$ was similarly evaluated per disturbance region and expressed as a percentage, and percentage of remaining habitat calculated as $\left(1-c_{i}\right)$. This represents an evaluation of potential habitat that will become irreversibly lost and will not become suitable again. We considered here all activities that will permanently modify the soil structure (construction and mechanized agriculture) and the presence of a seed bank.

Step 9 The target area per disturbance region was further adjusted to compensate for expected density-reducing human-related activities within the next 50 years and was expressed as an estimated percentage of remaining habitat $\left(r_{i}\right)$. This represents an evaluation of the effect of activities that will affect the species' density in the landscape. We considered here the following three activities: building construction (through wood use for construction and as fuel), grazing (removal of seedlings), and weather effects (droughts and floods). Once this step was completed a final estimate of the minimum target area for conservation per disturbance region was thus obtained.

Step 10 was not applied as no catastrophic disturbances are expected in the region. Based on a review of historical, geological and weather records, no volcanic eruption, earthquake, landslide, tsunami, hurricane wind or tornado are expected.

Step 11 was also not applicable to our case study because it was already incorporated within our approach in 42 disturbance regions, whereby Sand Forest and Woodlands targets were combined.

Step 12 The area of potential available habitat is divided by the final value obtained for the minimum target area for each of the 42 disturbance regions. This ratio gives managers a rapid estimate of the current availability of land for conservation. 
TABLE 3 Summary of the minimum area required for conservation per vegetation type and woody plant species in the whole study area, Tembe Elephant Park, and Tshanini Community Conservation Area (Fig. 2). The sum in hectares for each species represents the sum of all minimum areas for all disturbance regions in the site evaluated and that need to be conserved to have a satisfactory conservation outcome. The mean area represents the mean minimum area required for conservation per disturbance region. For Tshanini Community Conservation Area the mean could not be calculated as the site was encompassed within one disturbance region.

\begin{tabular}{|c|c|c|c|c|c|}
\hline \multirow[b]{2}{*}{ Species } & \multicolumn{2}{|c|}{ Whole study area } & \multicolumn{2}{|c|}{ Tembe Elephant Park } & \multirow{2}{*}{$\begin{array}{l}\text { Tshanini Community } \\
\text { Conservation Area } \\
\text { Sum (ha) }\end{array}$} \\
\hline & Sum (ha) & Mean \pm SE (ha) & Sum (ha) & Mean \pm SE (ha) & \\
\hline \multicolumn{6}{|l|}{ Sand Forest } \\
\hline C. schlechteri & $3,193.74$ & $76.04 \pm 40.34$ & 561.43 & $29.55 \pm 8.53$ & 7.74 \\
\hline N. hildebrandtii & $3,407.26$ & $81.13 \pm 42.74$ & 621.29 & $32.70 \pm 9.43$ & 4.94 \\
\hline \multicolumn{6}{|l|}{ Closed Woodland } \\
\hline H. ulmoides & $8,139.65$ & $193.80 \pm 102.82$ & $1,434.75$ & $75.51 \pm 21.79$ & 14.80 \\
\hline S. birrea & $10,302.72$ & $245.30 \pm 127.94$ & $1,969.60$ & $103.66 \pm 29.91$ & 9.54 \\
\hline \multicolumn{6}{|l|}{ Open Woodland } \\
\hline H. ulmoides & $22,842.49$ & $543.87 \pm 233.35$ & $7,835.94$ & $412.42 \pm 118.99$ & 4.50 \\
\hline S. birrea & $10,519.98$ & $250.48 \pm 133.74$ & $1,790.55$ & $94.24 \pm 27.19$ & 27.51 \\
\hline \multicolumn{6}{|l|}{ Sparse Woodland } \\
\hline H. ulmoides & $149,976.04$ & $3,570.86 \pm 1,539.16$ & $50,933.63$ & $2,680.72 \pm 773.43$ & 28.90 \\
\hline
\end{tabular}

\section{Results}

The exponential equation $\left(y=a \mathrm{e}^{b(x)}\right)$ provided the best fit $\left(R^{2}=0.43\right)$ between $F$-value and life expectancy and was therefore used to derive $F$-values for the selected species (Table 2). H. ulmoides had the highest F-value at 1,086 individuals and $N$. hildebrandtii the lowest at 186 . However, $H$. ulmoides required only a $14 \%$ increase of $F$ to derive the adjusted $F$-value, whereas $N$. hildebrandtii required a $40 \%$ increase to obtain the adjusted $F$-value (Table 1).

From the density $(D)$ and adjusted $F$, a target area representing the minimum viable area (Step 6) was calculated for each of the Sand Forest and Woodland species. The size of this area was then further refined based on the consideration of a group of reversible and irreversible disturbances likely to affect the area (Steps 7-9). See Appendices 1-2 for the full analysis.

The sum of all minimum and mean areas required for conservation per disturbance region for the entire region, as well as for the Tembe Elephant Park and Tshanini Community Conservation Area separately, are presented per species per vegetation unit (Table 3). The Sand Forest species required the smallest areas, with $C$. schechteri requiring a mean of 76 ha per disturbance region (range $8-1,706 \mathrm{ha}$ ), whereas $N$. hildebrandtii required a mean of 81 ha (range $5^{-1,808 ~ h a) . ~ T h e ~ m e a n ~ m i n i m u m ~ a r e a s ~ r e q u i r e d ~}$ for the Woodland species were greater. For $H$. ulmoides there was an increase in the area required from the Closed Woodland (mean 194 ha, range 148-4,349 ha) to the Open Woodland (mean 544 ha, range 5-9,752 ha), whereas the area requirements for $S$. birrea were similar in the Closed (245 ha; range: $10-5,411 \mathrm{ha}$ ) and Open Woodland (250 ha; range $28-5,657 \mathrm{ha}$ ).
From Step 12 it is evident that the availability of Sand Forest habitat far exceeds the minimum area required to conserve this vegetation type in a 50-year time span (Table 4). Only in disturbance region $\mathrm{D}_{5}$ (Fig. 2) is the ratio of available to required habitat $<1$. The Woodland analysis shows that some disturbance regions do not currently have enough habitat available $\left(\right.$ ratio $\left.<_{1}\right)$ for their conservation (Table 4). Of particular importance are disturbance regions $\mathrm{B}_{5}, \mathrm{C}_{5}, \mathrm{D}_{5}, \mathrm{E}_{2}, \mathrm{E}_{3}$ and $\mathrm{F}_{2}$, within Tembe Elephant Park, where insufficient habitat is available for at least one vegetation type and landscape species.

\section{Discussion}

One of the central questions in conservation science is 'How much is enough?' (Poiani et al., 2000; Svancara et al., 2005; Tear et al., 2005). No universally accepted method to obtain the answer has yet been developed. We based our investigation of the conservation adequacy of the Tembe-Tshanini complex using a simple population model (Burgman et al., 2001) to set targets for conservation. Population models have the advantage that they can deal with processes that affect the persistence of the species (Nicholson et al., 2006) and are therefore ideal for singlespecies investigations but not for multiple species planning (Moilanen \& Cabeza, 2002).

For both Sand Forest species, C. schlechteri and N. hildebrandtii, it appears that sufficient habitat is already conserved in the Tembe Elephant Park $(3,400$ ha) and informally conserved in the Tshanini Community Conservation Area (1,046 ha; Gaugris, 2008) to secure the future of both species and therefore the Sand Forest vegetation. Even in most of the disturbance regions covering land that is not 
TABLE 4 The ratio of available to required habitat per species (Step 12 of Burgman et al., 2001) in each of the evaluated disturbance regions (Fig. 2). A ratio $>_{1}$ indicates that sufficient available habitat exists to match the conservation requirements, whereas a ratio $<1$ indicates that insufficient habitat is available. Numbers in bold indicate disturbance regions where insufficient habitat is available for conservation of that landscape species.

\begin{tabular}{|c|c|c|c|c|c|c|c|}
\hline \multirow{3}{*}{$\begin{array}{l}\text { Grid } \\
\text { square } \\
\text { (Fig. 2) }\end{array}$} & \multicolumn{7}{|c|}{ Step 12, Ratio of available to required habitat (see Appendices) } \\
\hline & \multirow[b]{2}{*}{$\begin{array}{l}\text { C. schlechteri } \\
\text { (Sand Forest) }\end{array}$} & \multirow[b]{2}{*}{$\begin{array}{l}\text { N. hildebrandtii } \\
\text { (Sand Forest) }\end{array}$} & \multicolumn{3}{|c|}{ H. ulmoides } & \multicolumn{2}{|l|}{ S. birrea } \\
\hline & & & $\begin{array}{l}\text { Closed } \\
\text { Woodland }\end{array}$ & $\begin{array}{l}\text { Open } \\
\text { Woodland }\end{array}$ & $\begin{array}{l}\text { Sparse } \\
\text { Woodland }\end{array}$ & $\begin{array}{l}\text { Closed } \\
\text { Woodland }\end{array}$ & $\begin{array}{l}\text { Open } \\
\text { Woodland }\end{array}$ \\
\hline$\overline{\mathrm{A} 1}$ & 59.17 & 55.84 & 30.8 & 13.7 & 2.1 & 24.7 & 23.7 \\
\hline A2 & 103.55 & 97.72 & 53.8 & 24.0 & 3.6 & 43.3 & 41.4 \\
\hline A3 & 110.94 & 104.70 & 57.7 & 25.7 & 3.9 & 46.4 & 44.4 \\
\hline A4 & 12.33 & 11.63 & 6.4 & 2.9 & 0.4 & 5.2 & 4.9 \\
\hline A5 & 60.43 & 57.03 & 31.4 & 14.0 & 2.1 & 25.3 & 24.2 \\
\hline A6 & 115.41 & 108.91 & 60.0 & 26.8 & 4.1 & 48.2 & 46.1 \\
\hline A7 & 114.56 & 108.11 & 59.6 & 26.6 & 4.0 & 47.9 & 45.8 \\
\hline B1 & 70.63 & 63.83 & 36.6 & 6.7 & 1.0 & 26.7 & 29.4 \\
\hline B2 & 87.65 & 79.21 & 45.5 & 8.3 & 1.3 & 33.1 & 36.4 \\
\hline B3 & 94.39 & 85.30 & 49.0 & 9.0 & 1.4 & 35.7 & 39.2 \\
\hline B4 & 89.96 & 81.29 & 46.7 & 8.5 & 1.3 & 34.0 & 37.4 \\
\hline B5 & 21.01 & 18.99 & 10.9 & 2.0 & 0.3 & 7.9 & 8.7 \\
\hline B6 & 199.95 & 313.63 & 138.7 & 455.9 & 71.0 & 215.2 & 74.6 \\
\hline B7 & 137.54 & 129.80 & 71.5 & 31.9 & 4.8 & 57.5 & 55.0 \\
\hline $\mathrm{C} 1$ & 117.99 & 106.62 & 61.2 & 11.2 & 1.7 & 44.6 & 49.0 \\
\hline $\mathrm{C} 2$ & 138.64 & 125.28 & 71.9 & 13.2 & 2.0 & 52.4 & 57.6 \\
\hline C3 & 48.36 & 43.70 & 107.2 & 19.6 & 3.0 & 78.1 & 85.9 \\
\hline $\mathrm{C} 4$ & 36.27 & 32.78 & 80.4 & 14.7 & 2.3 & 58.6 & 64.4 \\
\hline $\mathrm{C} 5$ & 8.16 & 7.38 & 4.2 & 0.8 & 0.1 & 3.1 & 3.4 \\
\hline C6 & 9.58 & 9.05 & 5.0 & 2.2 & 0.3 & 4.0 & 3.8 \\
\hline $\mathrm{C} 7$ & 18.92 & 17.86 & 9.8 & 4.4 & 0.7 & 7.9 & 7.6 \\
\hline D1 & 123.61 & 111.70 & 64.1 & 11.7 & 1.8 & 46.7 & 51.4 \\
\hline D2 & 29.02 & 26.22 & 64.3 & 11.8 & 1.8 & 46.9 & 51.6 \\
\hline D3 & 19.34 & 17.48 & 42.9 & 7.9 & 1.2 & 31.2 & 34.4 \\
\hline D4 & 20.94 & 18.92 & 46.4 & 8.5 & 1.3 & 33.8 & 37.2 \\
\hline D5 & 0.19 & 0.18 & 0.2 & 0.1 & 0.0 & 0.2 & 0.2 \\
\hline D6 & 28.65 & 27.03 & 14.9 & 6.6 & 1.0 & 12.0 & 11.5 \\
\hline D7 & 21.92 & 20.68 & 32.7 & 14.6 & 2.2 & 26.3 & 25.1 \\
\hline E1 & 20.87 & 18.86 & 40.8 & 7.5 & 1.2 & 29.7 & 32.7 \\
\hline E2 & 14.38 & 12.99 & 28.1 & 5.2 & 0.8 & 20.5 & 22.5 \\
\hline E3 & 9.53 & 8.61 & 12.4 & 2.3 & 0.4 & 9.1 & 10.0 \\
\hline $\mathrm{E} 4$ & 4.61 & 4.35 & 6.0 & 2.7 & 0.4 & 4.8 & 4.6 \\
\hline E5 & 0.00 & 0.00 & 2.8 & 1.2 & 0.2 & 2.2 & 2.1 \\
\hline E6 & 0.00 & 0.00 & 2.5 & 1.1 & 0.2 & 2.0 & 1.9 \\
\hline E7 & 16.42 & 15.49 & 16.1 & 7.2 & 1.1 & 12.9 & 12.4 \\
\hline $\mathrm{F} 1$ & 11.70 & 10.57 & 13.7 & 2.5 & 0.4 & 10.0 & 11.0 \\
\hline $\mathrm{F} 2$ & 1.42 & 1.29 & 1.1 & 0.2 & 0.0 & 0.8 & 0.9 \\
\hline F3 & 9.67 & 9.13 & 7.6 & 3.4 & 0.5 & 6.1 & 5.8 \\
\hline $\mathrm{F} 4$ & 22.46 & 21.20 & 23.5 & 10.5 & 1.6 & 18.9 & 18.1 \\
\hline F5 & 21.14 & 19.95 & 22.1 & 9.9 & 1.5 & 17.8 & 17.0 \\
\hline F6 & 1.77 & 1.67 & 2.8 & 1.2 & 0.2 & 2.2 & 2.1 \\
\hline F7 & 17.62 & 16.63 & 18.4 & 8.2 & 1.2 & 14.8 & 14.2 \\
\hline
\end{tabular}

conserved the minimum area necessary for conserving the species is present. This implies that suitable environmental conditions still exist beyond the conservation areas and that there is a functional corridor between the two areas. Disturbance region $\mathrm{D}_{5}$ is the only one in which the area available for Sand Forest was less than the required minimum. Most of this disturbance region (95\%) is occupied by the village of Sicabazini, where the community resettled when they were relocated upon creation of the Tembe Elephant Park in 1983 (Matthews et al., 2001). To ensure the maintenance of ecological processes and overall conservation of the Sand Forest we recommend that a suite 
of Sand Forest patches of varying sizes be preserved within a network of reserves rather than in one single reserve (Possingham et al. 2000; Van Rensburg et al., 2000a,b; Gaugris \& Van Rooyen, 2008).

For the Woodland vegetation type the minimum area requirements for the two species investigated differed substantially. We recommend using the species that requires the largest area. For the Closed Woodland, therefore, at least 10,303 ha should be set aside (based on the calculations for $S$. birrea), whereas 22,843 ha of the Open Woodland should be set aside (based on the calculations for H. ulmoides). However, within the Tembe-Tshanini complex there is only 7,386 ha of Closed Woodland and 9,576 ha of Open Woodland and thus insufficient land is presently conserved to ensure the persistence of these vegetation types over the period considered. Outside these conservation areas the Closed and Open Woodlands are well represented. Due to the marginal subsistence agriculture value of the soils of the area (Eeley et al., 2001) and the high rate of emigration from this area to coastal towns, where tourism drives employment opportunities (Peteers, 2005), these woodlands may nevertheless continue to survive outside conserved areas.

Burgman et al. (2001) advocated the use of their method in regions where there is little available information on the species or vegetation dynamics, as is the case for Maputaland (Gaugris, 2008). In this context, the method fulfilled its promise to estimate the minimum area of each vegetation type that should be conserved. The minimum areas determined appeared realistic and it was possible to determine whether the areas currently set aside for conservation are adequate.

The weakest aspect of the method is that used to establish $F$, the minimum viable population size, without specialist knowledge or extensive life table information. A lack of detailed information (Cabeza \& Moilanen, 2001; Justus et al., 2008) or lack of reliability about the data, leading to uncertainty (Moilanen et al. 2006a,b), are two of the problems with which conservation planners have to contend. Although the models fitted to the published data did not have high $R^{2}$-values, the method provided a framework to calculate $F$ objectively. Additional information would improve the fit. The adjusted $F$ was derived by considering a range of ecological factors that are important for the long-term conservation of the species. These factors could readily be assessed using personal and expert knowledge. However, our attempts to establish $F$ and adjusted $F$ are preliminary and require revision. Future studies should focus on devising a simple and repeatable method of setting $F$ without knowledge of growth, mortality and recruitment rates. Perhaps a way of setting $F$ from size class distribution and abundance data could be investigated.

Species selection is crucial because the species are used as surrogates for conservation of an entire vegetation type.
A common conservation strategy has been to use umbrella species as surrogates for poorly known regional biota (Simberloff, 1998), similar to the use of indicator taxa in reserve design (Howard et al., 1998). However, evaluations of the use of umbrella or flagship species have indicated that they perform no better than randomly selected species (Andelman \& Fagan, 2000; Williams et al., 2000), although encouraging results have been obtained in Uganda (Howard et al., 1998). The selection of landscape plant species appeared to work adequately in this study. We recommend, however, that future studies should select one species per vegetation unit, rather than trying to bridge more than one vegetation unit with one species.

A major advantage of the method is its ease of use once it has been established for an area. The wide variety of quantitative and qualitative aspects considered allows further refinements to be made as new knowledge becomes available. The method can be adapted to include additional aspects (within Steps 7-9) such as agriculture, alien plants, urbanization and interface retention targets (Pressey et al., 2003), and additional aspects of the population biology of the species can be included to refine the adjusted $F$-value. By changing the values in the tables (Appendices 1-2) instantaneous results are obtained and therefore decisions can be made without extensive consultation. Using the tables a conservation manager can establish the minimum area of land that should be fully preserved in each disturbance region, and thus establish the area remaining for sustainable use. An additional advantage of the method lies in the possibility to scrutinize an area using a range of disturbance region sizes and therefore to balance conservation according to the scale of definition desired. We feel that the advantages of such a tool for conservation, especially outside formally conserved areas, justify applying the method even if data are deficient initially, if only to establish targets for conservation and areas for sustainable use.

A clear limitation must, however, be set on the size of the area under scrutiny. It should remain within the grasp and knowledge of the ecologist and experts tasked to set the relevant minimum viable areas. Should the area become exceedingly large the conditions are likely to be beyond the knowledge of the experts. This method appears suitable for setting targets by local people and experts. However, its applicability at a larger scale is more uncertain as a lot of definition would be lost. It would be possible to investigate the applicability of the method for a larger scale based on the results of many subregions, each considered as disturbance regions for the larger scale meta-analysis.

To conclude, the method described here is promising as it sets applicable limits and is relatively easy to use, replicate, update and refine. The total area that we considered was approximately five times larger than the combined areas of the reserves concerned, and we feel that the local 
dynamics of the ecosystems were appropriately represented within this total area.

\section{Acknowledgements}

This article is dedicated to Irmie Gaugris, who left us too early. We thank Caroline Vasicek for her insight and for reviewing the methodology, and four anonymous referees for their valuable comments. This research was supported by the National Research Foundation (South Africa) under Grant Number 2047386.

\section{References}

Andelman, S. \& Fagan, W. (2000) Umbrellas and flagships: efficient conservation or expensive mistakes? Proceedings of the National Academy of Science, USA, 97, 5954-5959.

Botes, A., McGeoch, M.A. \& Van Rensburg, B.J. (2006) Elephant- and human-induced changes to dung beetle (Coleoptera: Scarabaeidae) assemblages in the Maputaland Centre of Endemism. Biological Conservation, 130, 573-583.

Burgman, M.A., Possingham, H.P., LynCh, A.J.J., Keith, D.A., McCarthy, M.A., Hopper, S.D. et al. (2001) A method for setting the size of plant conservation target areas. Conservation Biology, 15, 603-616.

Cabeza, M. \& Moilanen, A. (2001) Design of reserve networks and the persistence of biodiversity. Trends in Ecology \& Evolution, 16, 242-248.

Cowling, R.M., Pressey, R.L., Sims-Castley, R., Le Roux, A., BaArd, E., Burgers, C.J. \& Palmer, G. (2003) The expert or the algorithm? Comparison of priority conservation areas in the Cape Floristic Region identified by park managers and reserve selection software. Biological Conservation, 112, 147-167.

Desmet, P.G. \& Cowling, R.M. (2004) Using the species-area relationship to set baseline targets for conservation. Ecology \& Society, 9(2), 11. Http://www.ecologyandsociety.org/vol9/iss2/art11/ [accessed 31 March 2009].

Eeley, H.A.C., Lawes, M. \& Reyers, B. (2001) Priority areas for the conservation of subtropical indigenous forest in southern Africa: a case study from KwaZulu-Natal. Biodiversity and Conservation, $10,1221-1246$.

Emanuel, P.L., Shackleton, C.M. \& Baxter, J.S. (2005) Modelling the sustainable harvest of Sclerocarya birrea subsp. caffra fruits in the South African lowveld. Forest Ecology and Management, 214, 91-99.

Fleishman, E., Murphy, D.D. \& Blair, R.B. (2001) Selecting effective umbrella species. Conservation in Practice, 2, 17-23.

GAUGRIs, J. Y. (2008) The impacts of herbivores and humans on the utilisation of woody resources in conserved versus non-conserved land in Maputaland, northern KwaZulu-Natal, South Africa. PhD thesis, University of Pretoria, Pretoria, South Africa.

Gaugris, J.Y., Matthews, W., Van Rooyen, M.W. \& Bothma, J. Du P. (2004) The vegetation of Tshanini Game Reserve and a comparison with equivalent units in the Tembe Elephant Park in Maputaland, South Africa. Koedoe, 47, 9-29.

Gaugris, J.Y. \& Van Rooyen, M.W. (2008) A spatial and temporal analysis of Sand Forest tree assemblages in Maputaland, South Africa. South African Journal of Wildlife Research, 38, 171-184.

Gaugris, J.Y., Van Rooyen, M.W. \& Van der Linde, M.J. (2007) Hard wood utilisation in buildings of rural households of the
Manqakulane community, Maputaland, South Africa. Ethnobotany Research and Applications, 5, 97-114.

Howard, P.C., Viskanic, P., Davenport, T.R.B., Kigenyi, F.W., Baltzer, M., Dickinson, C.J. et al. (1998) Complementarity and the use of indicator groups for reserve selection in Uganda. Nature, 394, 472-475.

Justus, J., Fuller, T. \& SARKar, S. (2008) Influence of representation targets on the total area of conservation-area networks. Conservation Biology, 22, 673-682.

Luoga, E.J., Witkowski, E.T.F. \& BALKWILL, K. (2000) Economics of charcoal production in miombo woodlands of eastern Tanzania: some hidden costs associated with commercialization of the resources. Ecological Economics, 35, 243-257.

Matthews, W. (2006) Contributions to the ecology of Maputaland, southern Africa, with emphasis on Sand Forest. PhD thesis, University of Pretoria, Pretoria, South Africa.

Matthews, W., Van Wyk, A.E., Van Rooyen, N. \& Botha, G.A. (2001) Vegetation of the Tembe Elephant Park, Maputaland, South Africa. South African Journal of Botany, 67, 573-594.

Moilanen, A. \& Cabeza, M. (2002) Single-species dynamic site selection. Ecological Applications, 12, 913-926.

Moilanen, A., Runge, M.C., Tyre, A., Carmel, Y., Fegraus, E., Wint L, B.A. et al. (2006a) Planning for robust reserve networks using uncertainty analysis. Ecological Modelling, 199, 115-124.

Moilanen, A., Wintl, B.A., Elith, J. \& Burgman, M. (2006b) Uncertainty analysis for regional-scale reserve selection. Conservation Biology, 20, 1688-1697.

Naughton-Treves, L., Kammen, D.M. \& Chapman, C. (2007) Burning biodiversity: woody biomass use by commercial and subsistence groups in western Uganda's forests. Biological Conservation, 134, 232-240.

Nicholson, E., Westphal, M.J., Frank, K., Rochester, W.A., Pressey, R.L., Lindenmayer, D.B. \& Possingham, H.P. (2006) A new method for conservation planning for the persistence of multiple species. Ecology Letters, 9, 1049-1060.

Petenrs, O. (2005) Poverty alleviation and sustainable development in Manqakulane, Northern KwaZulu-Natal, South Africa: a systemic approach using retrospective remote sensing and GIS. MA thesis, Vrije Universiteit Brussel, Brussels, Belgium.

Poinan, K.A., Richter, B.D., Anderson, M.G. \& Richter, H. (2000) Biodiversity conservation at multiple scales: functional sites, landscapes and networks. BioScience 50, 133-146.

Pooley, E. (1997) The Complete Field Guide to the Trees of Natal, Zululand and Transkei. Natal Flora Publication Trust, Durban, South Africa.

Possingham, H.P., Ball, I. \& Andelman, S.J. (2000) Mathematical methods for identifying representative reserve networks. In Quantitative Methods for Conservation Biology (eds S. Ferson \& M.A. Burgman), pp. 291-306. Springer Verlag, New York, USA.

Pressey, R.L., Cowling, R.M. \& Rouget, M. (2003) Formulating conservation targets for biodiversity pattern and process in the Cape Floristic Region, South Africa. Biological Conservation, 112, 99-127.

Reyers, B., Fairbanks, D.H.K., Van Jahrsveld, A.S. \& Thompson, M. (2001) Priority areas for the conservation of South African vegetation: a coarse-filter approach. Diversity and Distributions, 7, 79-95.

Rouget, M., Cowling, R.M., Lombard, A.T., Knight, A.T. \& Kerley, G.I.H. (2006) Designing large-scale conservation corridors for pattern and process. Conservation Biology, 20, 549-561.

Sanderson, E.W., Redford, K.H., Vedder, A., Coppolillo, P.B. \& WARD, S.E. (2002) A conceptual model for conservation planning based on landscape species requirements. Landscape and Urban Planning, 58, 41-56. 
SEDdon, P.J. \& LEECH, T. (2008) Conservation short cut, or long and winding road? A critique of umbrella species criteria. Oryx, $42,240-245$.

Simberloff, D. (1998) Flagships, umbrellas, and keystones: is single species management passé in the landscape era? Biological Conservation, 83, 247-257.

Smith, R.J., Goodman, P.S. \& Matthews, W. (2006) Systematic conservation planning: a review of perceived limitations and an illustration of the benefits, using a case study from Maputaland, South Africa. Oryx, 40, 400-410.

Svancara, L.K., Brannon, R., Scott, J.M., Groves, C.R., Noss, R.F. \& Pressey, R.L. (2005) Policy-driven versus evidence-based conservation: a review of political targets and biological needs. BioScience, 55, 989-995.

Tear, T.H., Kareiva, P., Angermeier, P.L., Comer, P., Czech, B., Kautz, R. et al. (2005) How much is enough? The recurrent problem of setting measurable objectives in conservation. BioScience, 55, 835-849.

Van Rensburg, B.J., Chown, S.L., Van JaArsveld, A.S. \& McGEOGH, M.A. (2000a) Spatial variation and biogeography of sand forest avian assemblages in South Africa. Journal of Biogeography, 27, 1385-1401.

Van Rensburg, B.J., McGeoch, M.A., Matthews, W., Chown, S.L. \& VAN, A.S. (200ob) Testing generalities in the shape of patch occupancy frequency distributions. Ecology, 81, 3163-3177.
Williams, P.H., Burgess, N.D. \& Rahbek, C. (2000) Flagship species, ecological complementarity, and conserving the diversity of mammals and birds in sub-Saharan Africa. Animal Conservation, 3, 249-260.

Yeh, H.-Y., Wensel, L.C. \& Turnblom, E.C. (2000) An objective approach for classifying precipitation patterns to study climatic effects on tree growth. Forest Ecology and Management, 139, 41-50.

\section{Appendices 1-2}

The appendices for this article are available online at http:// journals.cambridge.org

\section{Biographical sketches}

Jerome Gaugris is an environmental consultant specializing in the sustainable utilization of natural resources in sub-Saharan Africa. He currently works on ecosystem service delivery in a highly populated urban landscape in Burundi. Gretel VAN Rooyen specializes in plant adaptations to desert environments, with a particular focus on the Namaqualand region, and also supervises a conservation-based rural community development programme in Maputaland. 